\title{
How Benchmarking Supports Reengineering
}

\author{
Dr.-Ing. K. Mertins, Dipl.-Ing. S.Kempf, Dipl.-Ing. G.Siebert \\ Fraunhofer-Institute for Production Systems and Design Technology \\ (IPK). Division of Systems Planning \\ Pascalstr. 8-9, 10587 Berlin, Germany, \\ Tel: +49 (30) 39006 234, Fax:+49 (30) 3911037, \\ E-Mail: kai.mertins@ipk.fhg.de
}

\begin{abstract}
Far-sighted enterprises have always used to collect information about competitors and have always compared themselves. Nowadays, the combination of a strategic alignment with central processes, Reengineering and Benchmarking (Mertins, Kempf, Siebert, 1994-2) is an equipment which supports each enterprise effectively in the process of continually improving their performance.

An enterprise-wide, communicable illustration of processing and organizational structures in variable models (Jochem, Schallock, 1994) facilitates this process. On the basis of business processes benchmarking of processes and organizational structures across business lines is made possible.

Market changes are reflected in constantly modified objectives. A well-directed benchmarking supplies the standard values to attain, Reengineering initiates the accomplishment of the objectives by setting up new business processes. The business process indicates the improvements. At the same time it represents the initial position for the next restructuring process. With the outlined instruments the management of change will be easier.
\end{abstract}

\section{KEYWORDS}

Benchmarking, organizational benchmarking, business process reengineering, enterprise modeling. 


\section{STARTING POSITION}

In a turbulent environment with accelerated innovation cycles of products and manufacturing processes, with increasing customer demands in regard to quality at favorable terms and an outstanding after-sales-service and with regulative demands for an ecological production prices alone do not determine the chances of an enterprise on the market. In order to be successful in the long term enterprises have to be able to react at short notice to changes occurring on the market.

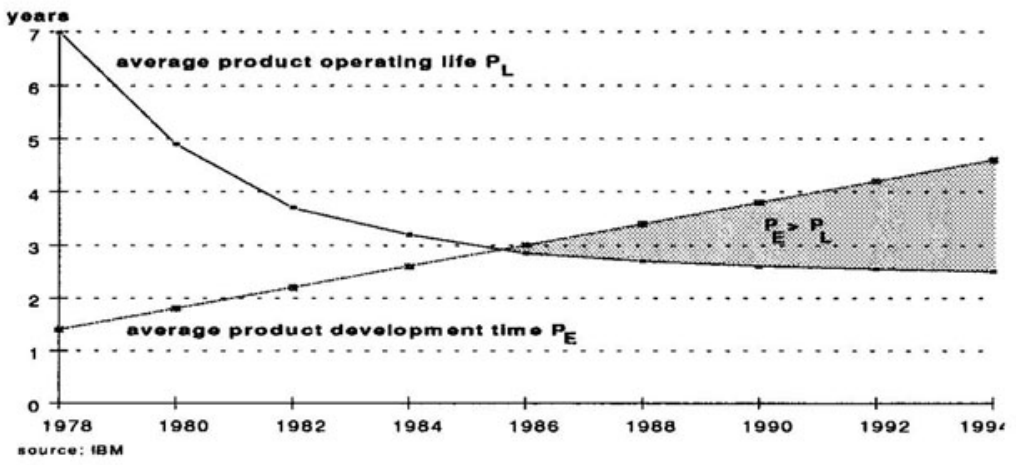

Figure 1 Change of product life and developing times.

While the development time of a product is becoming longer and the operating life is simultaneously becoming shorter (see Figure 1) enterprises today are prepared for the production of tomorrow's products, even though neither the structure nor the functionality of these products is yet known in detail. As past development processes have painfully made clear this is a difficult process of searching and orientating oneself. Branches of industry such as consumer electronics and photo technology have disappeared from Germany either completely or at least in part. And this was not only due to high wages and high nonwage labor costs of the location Germany, but also due to a much higher innovative power and higher customer orientation of the international competitors.

Therefore, the market shares constantly shift, not only between the triad United States, Japan and Europe, but increasingly to East European countries and Asian threshold countries . 


\begin{tabular}{|c|c|c|}
\hline $\begin{array}{c}\text { economic and managerial } \\
\text { concepts }\end{array}$ & $\begin{array}{l}\text { organizational } \\
\text { concepts }\end{array}$ & $\begin{array}{l}\text { technological } \\
\text { concepts }\end{array}$ \\
\hline $\begin{array}{l}\text { + JIT } \\
+ \text { CIM } \\
+ \text { segmented production } \\
+ \text { MRPP } \\
+ \text { MRP II } \\
\text { + Kanban } \\
\text { + strategic planning } \\
\text { + strategic control } \\
\text { + strategic management } \\
\text { + simulation }\end{array}$ & $\begin{array}{l}\text { - simultaneous te chnical planning (SE) } \\
\text { - simulation } \\
\text { - project management } \\
\text { - group technology } \\
\text { - central enterprise organization } \\
\text { - management holding } \\
\text { - value chain } \\
\text { - JIT - organization } \\
\text { - time - justified management } \\
\text { - project - orieitrted organization } \\
\text { - enterprise - oriented organization } \\
\text { - TaM } \\
\text { - la ader management } \\
\text { - time - oriented management } \\
\text { - lean management } \\
\text { - quality circles }\end{array}$ & $\begin{array}{l}+ \text { +CAM } \\
+ \text { CAP } \\
+C A D \\
+C A E \\
+C A Q \\
+C M M \\
+ \text { management information system (MIS) } \\
+ \text { decision support system (DSS) } \\
+ \text { executive information system (EIS) } \\
+ \text { information management } \\
\text { + integrated application software } \\
+ \text { office communication } \\
+ \text { global communication }\end{array}$ \\
\hline \multicolumn{3}{|c|}{ individual organizational solutions } \\
\hline
\end{tabular}

Figure 2 Available organization concepts.

Traditional enterprises have extensive central functions which work on Taylor's principle. It relies on a complex system of controls, gives away though the potentialities of well-educated and motivated employees. Superfluous hierarchies prolong the throughput and exhaust resources in double work which does not contribute to the adding of net value.

Often, an enterprise gets an impulse to adapt to the changing environment only if it loses market shares, if its profits dwindle, or if the customers are dissatisfied. The enterprises react with various methods of restructuring and slimdowns up to anorexia (see Figure 2). In this context the most discussed slogan is Business Process Reengineering, a term which should now be livened up.

\section{REENGINEERING}

All listed individual measures are basically aimed at improving a fundamental and decisive factor for the success of an enterprise: The competence to produce innovative high-quality products at marketable prices in due time. For that, enterprises should reflect upon their central competences, should formulate their strategic development objectives, and should then convert these objectives into solid concepts. Reengineering - another term for the necessary restructuring process - understood as the radical reorganization of all company-wide business processes however, implies a fundamentally new beginning without permanently looking at the way work processes used to proceed.

Hammer and Champy define enterprise processes as bundles of activities which require one or more different inputs and which produce a valuable result for a customer (Hammer, Champy, 1994). For the characterization of business processes they suggest quoting, besides the name of the business process, the beginning and end of the process in order to emphasize the nature of a process. They mention five frequently occurring business processes:

- Production: acquisition up to delivery. 
- Product development: rough design up to prototype.

- Sale: prospect up to order.

- Order processing: order up to payment.

- Customer service: Inquiry up to solution of the problem.

For the design of business processes Hammer and Champy coined the term Business Reengineering. They define Business Reengineering as the fundamental reconsideration and radical Redesign of enterprises or essential enterprise process. The results are improvements in decisive, nowadays important and measurable performance figures in areas of costs, quality, service and time (Hammer, Champy, 1994).

Fundamental reconsideration is understood as the non-presumptive scrutiny of the course of operations. The objective of this activity is determining and examining those unspoken rules and assumptions which are the basis for the operations. Radical Redesign is understood as the entire reorganization of the enterprise disregarding all existing structures and procedures. An improvement, expansion or modification is rejected explicitly. Improvement is understood as an improvement of the indicators of the performance figures by more than $10 \%$.

Improvements in this order have been made (see Figure 3). In addition, a high proportion of enterprises attained their objectives.

Naturally, the success of Reengineering is tempting, the risk of this radical approach however, is seen by enterprises likewise. One has to look for ways to minimize the risks and to utilize the potentials of Business Reengineering fully. The potential for success is to be increased by proceeding systematically and continually in all Reengineering projects.

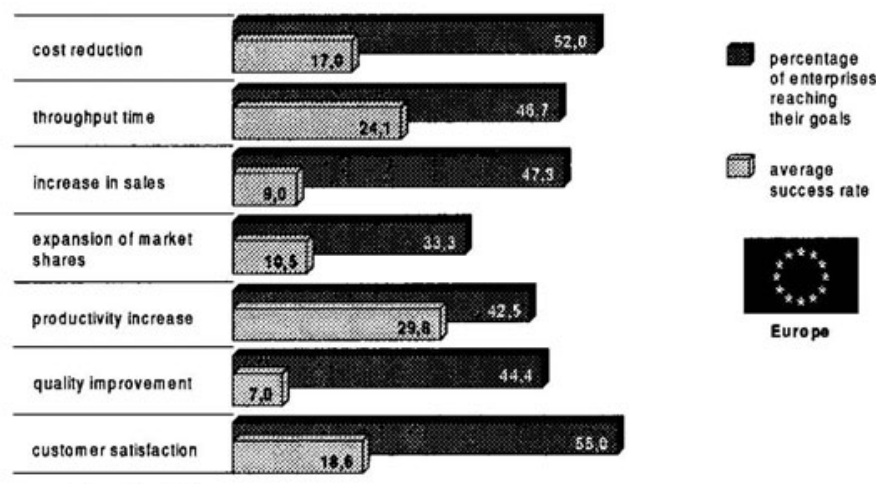

source: Wirtschafts Wocho

Figure 3 Improvement of results through Reengineering in Europe.

Among others, Reengineering is supported effectively by

- concentrating on the central processes,

- enterprise modeling and

- benchmarking. 


\section{CONCENTRATING ON THE ESSENTIALS}

Regardless of the cause for the restructuring, a fundamental Reengineering of an enterprise should proceed from the product itself and the processes to efficiently develop and manufacture the product. Business processes serve to add value to products in the enterprise. The direct value adding takes place in production and assembly. Accordingly, the manufacturing process must the main reference point of all activities undertaken to strengthen the enterprise's competence and ultimately the profits (Mertins, Edeler, 1993).

Traditionally-matured production structures are cumbersome and thus complicate the realignment with the efficient manufacturing of innovative products. Often, they also undermine a flexible reaction on market demands. The available high level of technical knowledge of engineers and specialists is to be employed in strategically developable and innovative fields instead of in perfectly attuned operative processes. Their potential should be tapped in flexibly structured units of the factory.

The planning of flexible factories for complex products requires optimizing the strategic share of in-house manufacturing hand in hand with the design of production structures. It is necessary to find the optimal answer to the questions:

- What is the central business? and

- How do we accomplish it?

The decision which products or structural components remain in the enterprise can not occur any longer operationally, e.g. according to costs. It must be considered as a strategic policy decision which eventually determines the alignment of the enterprise with its specific central processes.

Strategic products and their central structural components include:

- bearers of constructive and manufacturing engineering know-how,

- development-determining for the innovative potential of the enterprise,

- decisively for the market position / image and

- designed optimally for the advantage of the customer.

Structural components not characterized by these criteria should be passed to external contractors in order to influence the communication and coordination costs positively. Competence deficits of the enterprise may not be accepted, though.

Concentrating the development and production competence - and with that also limited capital appropriations - on the predetermined central structural components is suitable, if sufficient products and structural components are manufactured in the enterprise, to realize significant production cost advantages towards competitors.

To produce central structural components the processes - or business processes - of products, resources and orders in the production and in operations scheduling are described model-oriented in the sequential steps of Reengineering. One can derive the central process of the respective enterprise from the survey of the corresponding processes (see Figure 5).

After a corresponding connection with spatial and organizational aspects structural units, in the sense of largely self-regulating organizational units, are formed along the value adding chain. 


\section{BENCHMARKING "TRIGGERS" REENGINEERING}

Central elements of each benchmarking are:

- aiming, i.e. defining an objective for the development of the enterprise,

- measuring, i.e. permanently examining the process codes,

- comparing, i.e. examining whether the goals were accomplished or measuring against the best, and

- designing, i.e. converting the results.

In this sense benchmarking (Camp, 1989) can be a permanent inspiration, a constant incentive to continually improve the own business processes (see Figure 4).

The objective of internal and external benchmarking is to broaden one's mind, disclose deficits through the comparison with competitors and to solidify innovative processes stably (Mertins, Kempf, Siebert, 1994-1).

Usually, the comparison takes place between enterprises of the same branch of industry. An additional use may be made possible by comparing business processes from different branches of industry.

A "classifying benchmarking" across business lines is only possible if business processes can be portrayed comparably. The Kanban principle as a supply control system in the automobile industry was discovered by chance in a supermarket. It was considered abstractly as a business process and put into action. When applying benchmarking across business lines such potentials may be developed systematically.

Benchmarking, as a way to deal with predefined comparable figures, must not be limited to business processes. For many years it has been employed in EDP technology where response times are given for standardized arithmetic operations. In the other extreme there are comparable figures for huge structural units like national economies and large corporations. Statements about the efficiency of company-related structural units, e.g. central process units, are usually not carried out. Such organizational units however represent small, clearly visible and thus easily susceptible substructures, which eventually, added up with all other substructures of the respective enterprise, yield the total efficiency of the enterprise. 


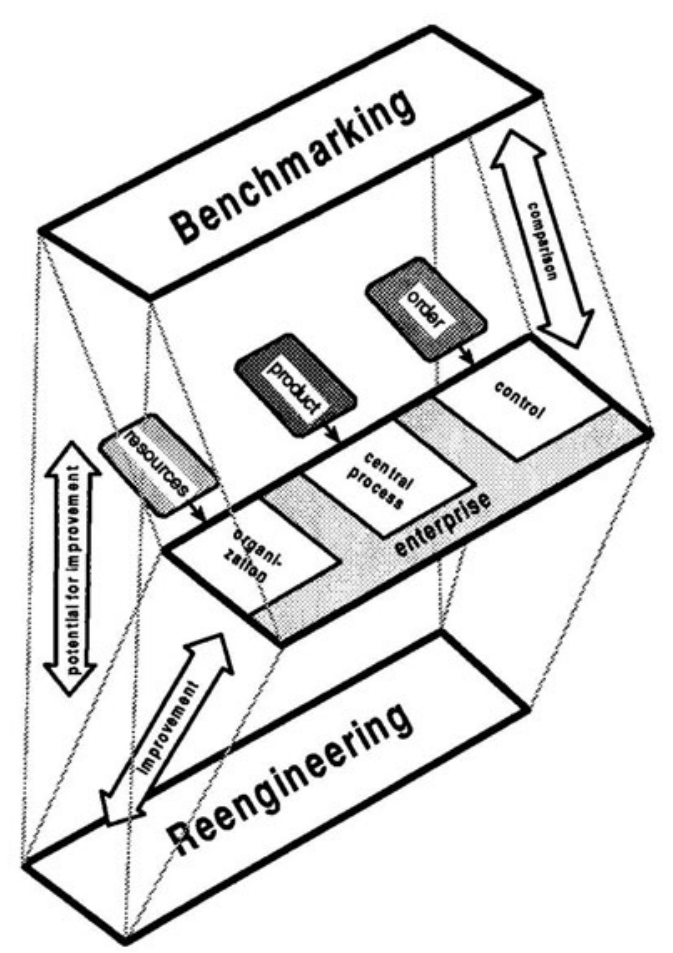

Figure 4 Comparison and improvement of the enterprise processes.

\section{ORGANIZATIONAL BENCHMARKING}

Measuring the performance of organizational units, e.g. of manufacturing segments or of islands of automation, used to be done subsequently, as a measurement of effects (Wildemann, 1988, Klingenberger, 1987). Of the effects one was able to determine partial benchmark values such as turnover rates, net value added per capita, and throughput times. There are different code systems (Troßmann, 1992) which measure the degree of efficiency. Most of these however, refer to figures which are only calculable for the whole corporation. In most cases, the determination of the efficiency of smaller organizational units, which should have been developed by Reengineering, were not related to the length of time and the cost in the indirect areas. Nowadays, the calculation of process costs improves this approach.

Comparative values do not include a description of the features which led to these effects. An organizational unit develops its efficiency through the interplay between people, machines and other resources. Staff members develop their optimal performance only if the work tasks are demanding, if social interaction is enabled and if opportunities for further education are opened up. To a certain degree this has been taken into consideration in the approach of the 
assessment of economical efficiency developed 15 years ago. The work system value (ASW) (Metzger, 1977) originating in the utility value analysis (Zippe, 1979) states, if one is somewhat experienced in working with codes, quite a bit about quality of a work system. These means allow an assessment of flexibility and other values which are difficult to quantify, particularly in personnel-intensive areas, such as assembly (Stiefel, 1989).

On a long-term basis it is necessary however, to develop a standard which enables production engineers to assess a production by the benchmark figures. This requires a generally accepted definition of

- the supporting functions belonging to the central process,

- the dimension figures and their reference values and

- the procedure of determining the comparative figures.

It is suggested to adopt the dimension figures and the reference values described in figure 5 . In order to determine the values an enterprise should be able to gather most data from controlling. If it is unable to do so the information processing of this enterprise should be questioned. Information about the attractiveness of work is to be determined by interviews and charts of activity valuation procedures.

This organizational comparison should not be limited to the organizational unit, but should include all functions contributing to the value adding processes. For example, all programming expenditures should be included regardless of whether the actual programming takes place in the workshop or in a central service department (see Figure 6).

The need for such an approach is underlined by the MIT study of the automobile industry. For reasons of simplification only direct manufacturing processes, e.g. carcasses, were examined. The determined figures on processing times and errors were criticized, among other reasons, because the study had left out the organizational dimension, which includes high fixed costs. The continuation of this study by the International Motor Vehicle Program (IMVP) will reinforce this direction. 
It is thus possible to compare the expenditure and efficiency of enterprises which are organized rather centrally with such enterprises which a more decentralized structure.

At the moment, we do not consider the departments of finance services, marketing, sales, services or product development. Relevant comparative standards, as they exist for manufacturing organizational units, would have to be developed accordingly.

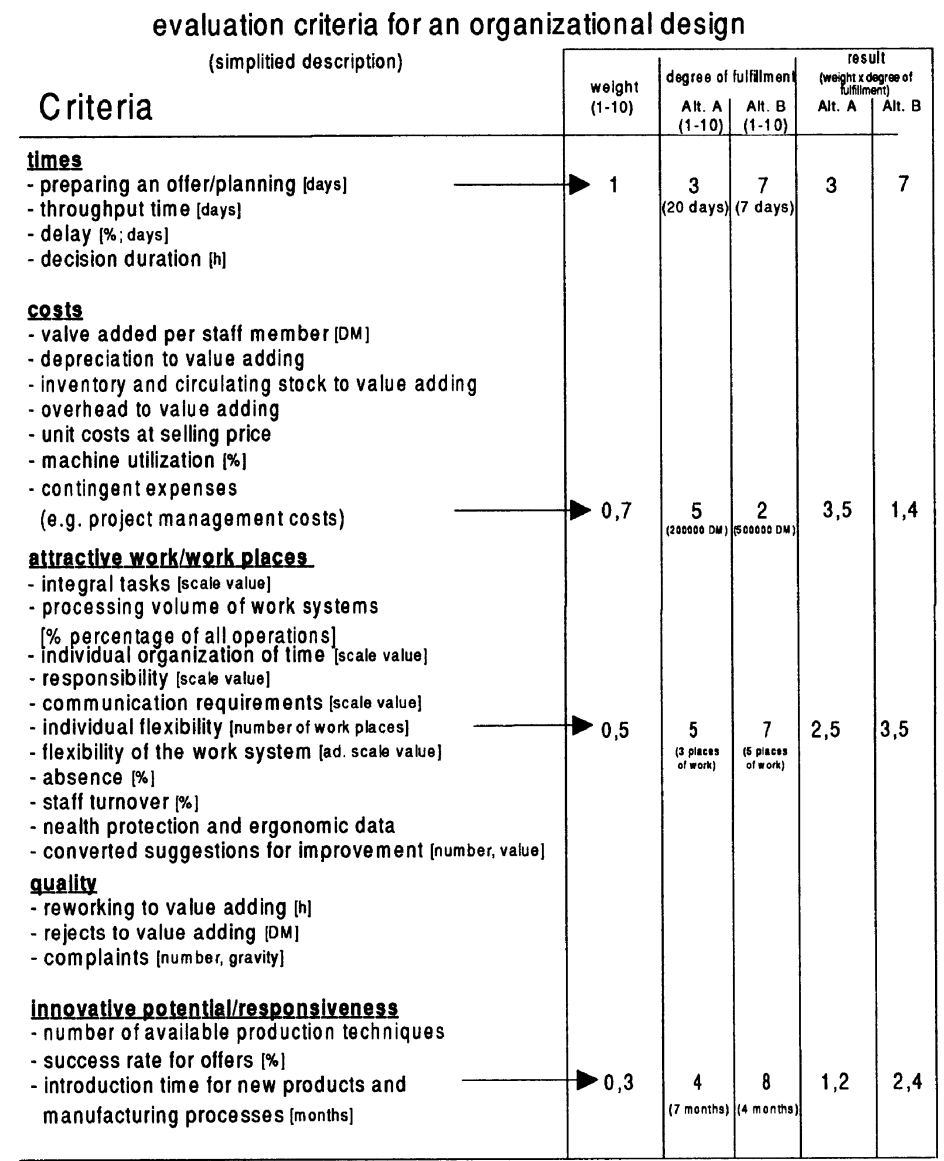

Figure 5 Measuring figures of organizational benchmarking. 


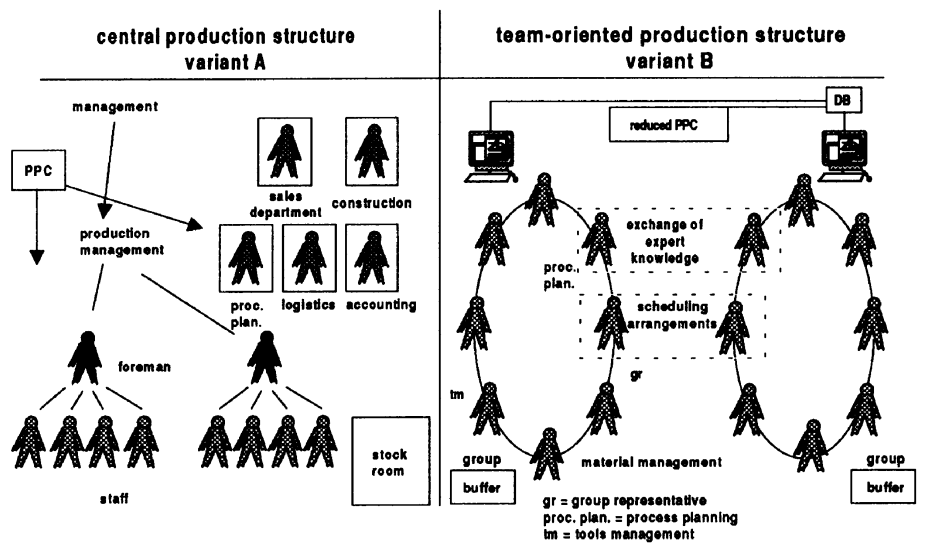

Figure 6 Delimitation of examination units through business processes.

\section{REFERENCES}

Camp, R. (1989). Benchmarking: The search for Industry Best Practices that lead to Superior Performance. ASQC Quality Press.

Hammer, M. and Champy, J. (1994). Business Reengineering. Frankfurt. New York.

Jochem, R. and Schallock, B. (1994). Partizipative Gestaltung gesamtbetrieblicher Strukturen mit PadeS und IUM. In: Mertins, K.(Hrsg.): Gestaltung teamorientierter Produktion. (Tagungsband) Berlin.

Klingenberger, H. and Kränzle, H.-P. (1987). Humanisierung bringt Gewinn; Modelle aus der Praxis; Band 2, Fertigung und Steuerung, Eschborn.

Mertins, K. and Edeler, H. (1993). Erfolg durch Konzentration auf Kernprozesse durch durchgängige Auftragssteuerung. ZwF 88, no. 10, p. 489-491.

Mertins, K., Kempf, S. and Siebert, G. (1994-1). Benchmarking Techniques. IFIP Conference, Trondheim, Norway.

Mertins, K., Kempf, S. and Siebert G. (1994-2). Benchmarking ein Managementwerkzeug. ZwF 89, no. 7-8, p. 359-361.

Mertins, K., Süssenguth, W. and Jochem, R.(1994). Modellierungsmethoden für rechnerintegrierte Produktionsprozesse. München, Wien.

Metzger, H. (1977). Planung und Bewertung von Arbeitssystemen in der Montage. Mainz.

Spur,G., Mertins, K. and Jochem, R. (1993). Integrierte Unternehmensmodellierung. Berlin, Wien, Zürich.

Stiefel, K.-P. (1989). SIGMA - Ein Instrument zur Bewertung aufbauorganisatorischer Gestaltungsmaßnahmen. IAO Sonderdruck, Stuttgart.

Troßmann, E. (1992). Kennzahlen als Instrument des Produktionscontrolling. In: Handbuch der Produktionsorganisation, Hanser.

Wildemann, H. (1988). Die modulare Fabrik - Kundennahe Produktion durch Fertigungssegmentierung. München.

Zippe, B.-H. (1979). Die betriebswirtschaftliche Beurteilung neuer Arbeitsformen. Mainz. 


\section{CURRICULUM VITAE}

\section{Dr.-Ing. Kai Mertins}

Dr.-Ing. Kai Mertins was born 1947 in the Federal Republic of Germany. After studying Control theory in Hamburg and Economy together with production technology at the Technical University of Berlin, he became member of the scientific staff of the University Institute for Machine Tool and manufacturing Technology (IWF), Berlin/FRG. Since 1983 he had been head of the department "Production Control and Manufacturing Systems" at the Fraunhofer-Institute for Production Systems and Design Technology (IPK), Berlin/FRG, where he has been Director for Planning Technology (President: Prof. Dr. h.c. mult. Dr.-Ing. G. Spur) since 1988. He has more than 15 years experience in design, planning, simulation and control of flexible manufacturing systems (FMS), manufacturing control systems (MCS), shop floor control systems, and computer integrated manufacturing (CIM). He was General Project Manager in several international industrial projects and gave lectures and seminars at the Technical University Berlin, Polytechnic Nottingham/UK, Czech Republic, Indonesia and China. Special field of interest: Manufacturing strategy development, planning for production systems, shop floor control and simulation.

\section{Dipl.-Ing. Stefan Kempf}

Born 1963.

Dipl.-Ing. in Mechanical Engineering at the Technical University of Berlin, Germany.

Mr. Kempf is working for the Fraunhofer-Institute for Production Systems and Design Technology (IPK) at the department Planning Technology since 1990. Since 1994 he is Head of the Group Benchmarking and Manager of the German Information Center Benchmarking.

His working areas are the planning of production systems, management consulting, application of grouptechnology, management of teams working on large software projects and developing software and benchmarking.

\section{Dipl.-Ing. Gunnar Siebert}

was born 1963 and after studying Industrial Engineering at the Technical University of Berlin he is working for the Fraunhofer-Institute for Production Systems and Design Technology (IPK), Berlin/FRG at the department Planning Technology. Since 1992 he is the Manager of the CIM Technology Transfer Center in Berlin/Brandenburg. Since 1994 he is Manager of the German Information Center Benchmarking.

His working areas are management consulting, establishing logistics systems, introduction and establishing of CIM-Systems and benchmarking. 